\title{
PERSONALITY REQUIREMENTS FOR UKRAINIAN AND CZECH MANAGERS CREATING BRANDS AS A COMPETITIVE ADVANTAGE
}

\section{- Zuzana Wroblowska}

\begin{abstract}
A strong brand has become increasingly important for success in global competition across market segments. There is no doubt that to succeed in their job role, brand managers must possess abilities, personality traits and concomitant soft skills that arise from these traits. The staff responsible for the brand management process deserves the attention of the professional community. The purpose of this article is to analyse, compare and discuss requirements for brand managers when they are first approached by their prospective employers in Ukraine and the Czech Republic. The research project was conducted to confirm that innovative and analytical skills are among the most frequent demands that candidates for the post of brand manager are confronted with at the beginning of the recruitment process. Using a summative content analysis, the word/phrase frequency of personality traits and skill requirements in job advertisements was studied. A requirement occurrence comparison between Ukraine and the Czech Republic showed some differences. Creativity requirements were predicted to appear more often in the Ukrainian set of job advertisements due to the emphasis placed in this country on an innovative approach in an internationally competitive environment. The differences in employer expectations supported by a set of psychological requirements placed on candidates for the position of brand manager inspire the discussion of the role the brand manager.
\end{abstract}

Keywords: brand manager, competition, content analysis, personality, recruitment, skills JEL Classification: D83, M12, M31, M51

Received: November, 2018

1st Revision: January, 2019

Accepted: February, 2019

\section{INTRODUCTION}

Experts agree that human capital is the intangible asset which generates most competitive advantages, with certain characteristics of personnel representing the most flexible and dynamic factor. Powerful brands play an important role in striving for a competitive advantage, with brand managers being accountable for both tactical day-to-day decision-making and the strategic development of assigned brands in an overwhelming majority of companies. Key brand managerial responsibilities have been described, e.g. by Upshaw (1995), Kapferer (1998), Keller (2008) and 
De Chernatony (2009). In recent years, the range of duties of brand managers has expanded since the social forces and trends that have shaped the first two decades of the 21st century have changed markets, forcing companies to adopt new attitudes and practices. Brands are supposed to be managed effectively so that they can adapt to the shifting business environment, thus enhancing their competitive positions. Increasingly, key areas of brand manager responsibilities are designed in a similar way to those of marketing directors. In addition to the development and implementation of brand positioning strategy, innovation and activation, "heavy-weight" brand managers are also in charge of marketing strategy, aiming to drive the performance of the brand. In order to succeed, they make and implement marketing plans in close cooperation with external partners and internal company departments (Sales, Business Development, Operations, etc.).

Obviously, brand managers must acquire adequate knowledge and skills, and possess certain personal traits and qualities as well as exhibit developed behavioural competencies necessary for efficient brand management performance. Since a comprehensive up-to-date set of requirements employers impose on brand managers was not available in the literature reviewed, it seems apparent that there is enough space for empirical research in this field. Based on secondary data, it is safe to assume that a brand manager is a representative of knowledge workers. Questions arise as to how important is brand manager creativity for employers, along with whether creativity ranks among the most preferable requirements for brand manager candidates.

This issue was tackled by Wroblowská (2016a), who, having conducted empirical research in 2015 applying Berelson's method of content analysis, verified that Czech employers consider brand managers as skilled knowledge workers, which in turn influences the recruiting and hiring process in filling vacancies. This very finding was confirmed in the US states of California, New York and Illinois in the same year (Wroblowská 2017a; 2017b). In 2017, similar empirical research was carried out in Ukraine using the previously tested summative method of content analysis by which Ukrainian employer expectations were examined. A discussion of the requirements for brand manager positions in different countries followed.

Published job advertisements can aid researchers in understanding the range of individual dispositions and skills required for particular positions. Ads are supposed to clearly indicate core competencies, with various amounts of details provided by different employers (Dunbar at al. 2016). Recruitment ads today are generally available online, allowing for reduced advertising costs, better access and ongoing updates; for details see Kaba (2017) and Noe et al. (2017). For these reasons, vacancy advertisements were used as a source of data.

The present study involves a summative content analysis of the occurrence of soft skill and personality descriptors sought in candidates for brand manager positions. Numerous authors have used content analysis in a similar way; see, for example, recent studies focusing on librarians (Detmering \& Sproles, 2012; Triumph \& Beile, 2015; Kaba, 2017), logisticians (Kovacs et al., 2012), and entry-level foresters (Bettinger \& Merry, 2018).

The paper presents the requirements to be met by brand managers when they are first approached by advertisers in the Czech Republic and Ukraine. The research assumption regarding the similarity of requirements for brand manager posts in the two countries has been verified, with the hypothesis testing described in the Results and Discussion sections below. 


\section{LITERATURE REVIEW}

\subsection{Marketing management and brand management}

Marketing was once viewed as a set of activities and as a customer- and market-driven concept of management. Now, however, it has been defined as "the activity, set of institutions, and processes for creating, communicating, delivering, and exchanging offerings that have value for customers, clients, partners, and society at large" (Kotler \& Keller, 2012, p. 5). The cited authors argue that social transformation has affected marketing to such an extent that it now requires a more extensive range of skill sets, with greater efforts needed to satisfy the ever-evolving needs of both stakeholders and the general public. Marketing management, according to Kotler \& Keller (2012, p. 5), is defined as "the art and science of choosing target markets and getting, keeping, and growing customers through creating, delivering, and communicating superior customer value". Product management fulfils requirements created by a new paradigm, adopting information-, process- and relationship-oriented approaches (Achrol \& Kotler, 2012). Aumayr (2006) describes marketing as a managerial concept focused on the necessity for the coordination of products and product groups. Tomek \& Vávrová (2009) explain that product management is "a process of product creation and development which corresponds to the market's needs", admitting that the "practical perception of product management" can bring about various levels of status "for product management and thus also of employees carrying out this work".

Gorchels (2005) as well as Kotler \& Keller (2012) imply that companies producing packaged goods prefer an integrated form of product and brand management, with the latter authors stressing that product-specific management requires adequate resources for each category of goods and services. Keller (2013) highlights the difference between a product and a brand, the former referring to anything offered to the market, the latter a broader concept involving the features that distinguish the product from competing ones. Based on holistic marketing philosophy, Kotler \& Keller (2012) argue that building strong brands represents a specific set of tasks which make up a successful marketing management and leadership environment. Aaker (1991, p. 6) has defined a brand as "a distinguishing name and/or symbol (such as a logo, trademark, or package design) intended to identify the goods or services of either one seller or group of sellers, and to differentiate those goods or services from those of competitors". Kotler \& Pfoertsch (2006, p. 3) state that brands meet the same goals in B2B markets as in consumer markets, because "they facilitate the identification of products, services and businesses, as well as differentiate them from the competition". The essence of brand management was captured by Kapferer (1998), who defined the concept of brand identity, underlining the pre-eminence of strategy and a consistent, integrated vision. Aaker (1996) designed another important concept, the so-called Brand Equity Ten model for measuring brand value. The establishment of brand identity is one of the four steps of the Customer-Based Brand Equity (CBBE) model, allowing the brand manager to build a close, long-term relationship between the brand and the consumer (Keller 1993).

To develop a set of requirements for the post of brand manager means to describe her/his role in the strategic brand management process. The four strategic, tactical and operational steps are 
as follows: brand positioning, brand marketing, brand performance measurement and interpretation, and brand equity growth and sustainability; see Keller (2013). In line with outcomes of intellectual capital research conducted by Nguyen, an improved customer intellectual, behavioural and sensory experience with a brand is what brand managers should primarily strive for; see Nguyen et al. (2015). The findings indicate that the set of main tasks expands, depending on impacts on the structure of requirements to be delivered by a brand manager. Despite current human factor requirements in brand management not being explicitly specified by Kotler \& Keller (2012), their implicit complexity can be inferred from the authors' inclination towards the involvement of whole brand-asset management teams supported by senior executive management.

\subsection{Human capital}

The widespread acceptance of brands as significant intangible assets is confirmed by Abdolmohammadi (2005). Brands are among the factors contributing to intellectual capital, defined by Subramaniam \& Youndt (2005) as "the sum of all the knowledge available to the organization that companies could utilize and use to achieve and maintain a competitive advantage". Intellectual capital comprises human, organizational and social capital, the latter two components consisting of institutionalized knowledge owned by organizations, and knowledge derived from the network of internal and external relationships, respectively. Bontis (1999) clarified the definition of human capital given by Schultz (1981), explaining that human capital represents the human factor in the organization, combined intelligence, skills and experience, that gives the organization its distinctive character. Human capital and knowledge management are closely related. "Knowledge worker" is a phrase first coined by Drucker (1993) to mean "individuals who have high levels of education and special skills combined with ability to apply these skills to identify and solve problems". Their work consists in creating, distributing or applying knowledge; see Mládková (2004). Knowledge workers constitute a heterogeneous group. Mládková (2008, p. 21) applied the original KWP classification using two dimensions - "the value added to performance by tacit knowledge" and "golden skills required for the position or necessity for work", including creativity, autonomy and ability to solve problems among the so-called golden skills of knowledge workers. Truneček (2003) highlighted the skills and capabilities of the knowledge workers to think contextually, learn constantly and work flexibly, independently and in an emotionally intelligent way.

\subsection{Personal determinants of performance and behavioural competencies}

There are many factors that can affect knowledge workers' performance. Internal ones are personal determinants, including a range of prerequisites for doing the job. Those closely related to work performance are individual dispositions and psychological attributes, which determine workers' ability to accomplish assigned tasks; see, e.g. Štikar et al. (2003), Armstrong (2006) and Noe et al. (2017). There are many personal attributes, usually referred to as "traits", indicating personality characteristics that distinguish one person from another, having the same manifestations under different circumstances; see Hall et al. (1997). Numerous personality studies try to divide the human mind into stable functional areas. According to Nakonečný (1998), attempts to 
unify various factor analytic models led to the selection of reliably determined, most significant factors, the so-called Big Five structure being one of the models. The taxonomy of personality traits thus remains an open research field.

Traits as units of human personality are "smaller" than behavioural competencies. According to Armstrong (2006, p. 160), quoted literally, the definition is "behavioural expectations, i.e. the type of behaviour required to deliver results under such headings as teamwork communication, leadership and decision-making. They are sometimes known as soft skills". The author admits that there are more interpretations, arguing that "competencies represent the language of performance. They can articulate both the expected outcomes from an individual's efforts and manner in which these activities are carried out" (Armstrong, 2006, p. 159). Noe et al. (2017, p. 701) interpret competencies as "a set of skills, knowledge, and abilities and personal characteristics that enable employees to perform their jobs".

Personality traits of creative people are assumed to overlap with the characteristics of knowledge workers; see, e.g. Drucker (1999), Truneček (2003), Davenport (2005) and Mládková (2008). Different research views on creativity determine different definitions and conclusions; cf. Franková (2011). According to Hlavsa (1985), creativity is a multi-component competency comprising imaginative, heuristic and schematic ingredients. The latter component encompasses basic thought operations and logical and systematic thinking, problem solving is part of the heuristic component, intuition and fantasy belonging to the imaginative component. Pitra \& Mohelská (2015, p. 312) define creativity as "the ability of person or of a group of persons to analyse a problem, find its solution and open ways how to bring this solution into life". Finally, Teresa Amabile's componential model of creativity is worth mentioning; see Amabile (1998). It assumes that if people want to fully develop their creativity, they must meet the three conditions set out by the model - "expertise in task", "creative thinking skills" (cognitive abilities and processes) and "motivation”; see Franková (2011, pgs. 93-94).

\section{OBJECTIVES AND METHODS}

The purpose of the study is to present and discuss interim outcomes of an ongoing research project. The empirical research objective is to identify the requirements for candidates for brand manager positions at an early stage of the recruitment process when advertisements for vacancies are released.

The background of the paper is based on an analysis of secondary data drawn from the following three types of reference literature - printed scientific and professional monographs and paper collections (under the headings of "brand management" and "product management"), reviewed scientific papers (via EBSCO service, using key words "personality traits", "knowledge", "brand manager" and "job", preferentially utilizing the Web of Science database), and three other articles available online.

The primary research goal was to assess the supply of job opportunities for brand managers in the Ukrainian labour market. The following research hypothesis (1): “The set of requirements for candidates for the job of brand manager will confirm that a brand manager is one of the 
knowledge workers who have personality traits and concomitant soft skills that arise from these traits typical for creative people" guided the direction of the study.

The secondary objective was to identify potential differences in requirements for brand managers between Ukraine and the Czech Republic. To achieve this second goal, a research hypothesis (2) was established: "The personality requirements and soft skills requirements for brand managers in Ukraine and the Czech Republic do not differ".

An interdisciplinary approach was adopted, because both theoretical research and analysis of the current state of the issue required an insight into various fields of study. Empirical and logical methods were mostly employed, both analytic and synthetic reasoning being applied. A comparative method was also utilized to achieve the scientific aim.

For the study of online job advertisement texts, the proven method of content analysis - devised by Bernard Berelson for objective, systematic, quantitative description of text contents - was used; see Berelson (1952). Selected text segments have been transformed into an electronic form. The procedure of content analysis, according to Schwandt (2001), was carried out.

A subsequent analysis was focused on mapping personality traits and skills (supposed to be shared by creative knowledge workers) that are considered important by potential employers who find it necessary to include relevant requirements in job advertisements. The findings were categorized and coded, a summative analysis being then performed. The requirements of which occurrence frequency exceeded five percent in at least one of the data files were analysed. The classification of psychological characteristics inspired by a standard diagram of profession, as Hroník (2007) recommended, was used to sort out the published psychological requirements for brand manager positions.

Over five weeks between April 18 and May 23 2017, the ads for positions titled "Brand Manager" were collected from job vacancy advertisements available online (www.work.ua) from three selected regions of Ukraine (Kiev, Lviv, and Dnipropetrovsk). A total of 79 ads were gathered. When the position was offered under a different heading, e.g. "Junior Brand Manager", the advertisement was excluded from the set. After finishing this procedure, the final sample contained 74 adverts.

As with previous studies, see Wroblowská (2016b; 2017a), the present research has been designed to allow for comparison of older and current outputs, focusing on the exploration of job requirements in Ukraine and the extension of earlier findings' validity for the Czech Republic. In spite of different external and internal factors in Ukraine, as mentioned by Sokil \& Ubrežiova (2017), the author chose this very country to compare its set of requirements with that imposed on Czech brand managers since, according to MINFIN (2017), the expected GDP growth outlook for Ukraine over the data-collection period was between 2.1 and 2.3 percent, thus being almost the same as in the Czech Republic (at a time when the job ads appeared and both economies were in the same phase of the economic cycle).

In line with Rezanková (2007), the assumption of matching requirements for brand manager posts in the two countries was tested using Pearson chi-square statistics. Tests were performed at significance levels of $0.1,1$ and 5 percent to check whether the null hypothesis regarding independence of the analysed variable (on the sign representing the country where job advertisements were posted) can be rejected. 


\section{RESULTS AND DISCUSSION}

The aim of this study is to present and discuss the selected research outcomes, other results related to knowledge prerequisites, specialized skills, strategic and other general competencies of Ukrainian brand managers is published in another paper; see Wroblowská (2018).

\subsection{Results}

Over the four-week research period, 74 job advertisements posted online at www.work.ua were collected. Most advertisements (68.9 percent) were from Kiev, 24.3 and 6.8 percent were from Dnipropetrovsk and Lviv, respectively. Private organizations offered 93.2 percent of brand manager vacancies, employment agencies releasing only 6.8 percent of them. All the ads required at least one personality trait and/or cognitive ability.

In Tab. 1, the sorted data from advertisement texts are shown in the form of a frequency chart. This table also provides information about the results of the survey conducted in the Czech Republic. The Czech data collection took place in 2015. Data processing has been applied in the same way as in Ukraine; for details, please see Wroblowská (2016b). The sample of advertisements coming from the Czech career portal Jobs.cz consisted of 56 adverts, while in Ukraine, the same selection rules as mentioned above, having been applied, the sample of single ads totalled 74.

Tab. 1 encompasses data from the entire industrial spectrum in both countries.

It is to be noted that competency requirements appeared sporadically both in Ukraine and the Czech Republic. With a few exceptions, e.g. "leadership" competency, the advertisers preferred to highlight desirable personality traits and relevant soft skills.

Comparison of the occurrence frequency of requirements for brand manager applicants in Ukrainian and Czech advertisements is illustrated in Fig. 1.

Tab. 2 indicates that the representation of individual characters is different in evaluated groups of requirements. Since less than 50 percent of Ukrainian as well as Czech employers did not mention requirements regarding a candidate's character and self-perception, or features and skills associated with motivation and self-control, this table does not display the results of the evaluation of sets of all respective requirements.

Tab. 3 (included in Appendix) provides information on a group of performance prerequisites and abilities (shown in Tab. 1 under letter P). This table gives an idea of statistical independence test administration, the chi-square criterion being applied. The test was conducted at significance levels of $0.1,1$, and 5 percent to detect whether the null hypothesis concerning independence of the analysed variables can or cannot be rejected. 
Tab. 1 - Personality traits and skills required for brand managers (BM) in Ukraine and the Czech Republic. Source: Author's own research

\begin{tabular}{|c|c|c|c|c|c|}
\hline \multirow{2}{*}{ Group } & \multirow{2}{*}{ Personality Requirements and Skills } & \multicolumn{2}{|c|}{ BM Czech Republic } & \multicolumn{2}{|c|}{ BM Ukraine } \\
\hline & & $\mathrm{n}$ & $\%$ & $\mathrm{n}$ & $\%$ \\
\hline $\mathrm{P}$ & \multicolumn{5}{|l|}{ performance prerequisites and abilities } \\
\hline 1 & $\begin{array}{l}\text { organizational ability/able to set priori- } \\
\text { ties }\end{array}$ & 16 & $28.6 \%$ & 12 & $16.2 \%$ \\
\hline 2 & able to work independently & 20 & $35.7 \%$ & 3 & $4.1 \%$ \\
\hline 3 & results orientation & 13 & $23.2 \%$ & 18 & $24.3 \%$ \\
\hline 4 & systematic approach & 3 & $5.4 \%$ & 1 & $1.4 \%$ \\
\hline 5 & logical thinking/reasoning ability & 4 & $7.1 \%$ & 2 & $2.7 \%$ \\
\hline 6 & ability to handle multi-tasking & 2 & $3.6 \%$ & 5 & $6.8 \%$ \\
\hline 7 & conceptual thinking & 6 & $10.7 \%$ & 0 & $0.0 \%$ \\
\hline 8 & analytic thinking/analytical skills & 24 & $42.9 \%$ & 24 & $32.4 \%$ \\
\hline 9 & accuracy/attention to detail/preciseness & 5 & $8.9 \%$ & 6 & $8.1 \%$ \\
\hline 10 & creativity/able to innovate & 29 & $51.8 \%$ & 23 & $31.1 \%$ \\
\hline I & \multicolumn{5}{|l|}{ interpersonal skills and abilities } \\
\hline 1 & team player/team work ability & 15 & $26.8 \%$ & 12 & $16.2 \%$ \\
\hline 2 & $\begin{array}{l}\text { communication skills/ability to com- } \\
\text { municate well }\end{array}$ & 39 & $69.6 \%$ & 31 & $41.9 \%$ \\
\hline 3 & negotiation abilities/ability to convince & 8 & $14.3 \%$ & 12 & $16.2 \%$ \\
\hline 4 & presentation skills & 23 & $41.1 \%$ & 13 & $17.6 \%$ \\
\hline 5 & leadership abilities & 3 & $5.4 \%$ & 5 & $6.8 \%$ \\
\hline $\mathrm{O}$ & \multicolumn{5}{|c|}{$\begin{array}{l}\text { other psychological demands and requirements } \\
\text { traits and skills connected to motivation and self-control }\end{array}$} \\
\hline 1 & $\begin{array}{l}\text { able to take initiative/proactive ap- } \\
\text { proach }\end{array}$ & 21 & $37.5 \%$ & 13 & $17.6 \%$ \\
\hline 2 & able to work enthusiastically & 13 & $23.2 \%$ & 1 & $1.4 \%$ \\
\hline 3 & able to learn/willing to learn new things & 3 & $5.4 \%$ & 1 & $1.4 \%$ \\
\hline \multirow[t]{2}{*}{4} & self-assertiveness & 3 & $5.4 \%$ & 7 & $9.5 \%$ \\
\hline & \multicolumn{5}{|l|}{ vital capacity and temperament } \\
\hline \multirow[t]{2}{*}{5} & vital personality/dynamic personality & 7 & $12.5 \%$ & 8 & $10.8 \%$ \\
\hline & \multicolumn{5}{|c|}{ other psychological demands and requirements } \\
\hline 6 & flexibility & 23 & $41.1 \%$ & 2 & $2.7 \%$ \\
\hline 7 & mature and open personality & 4 & $7.1 \%$ & 0 & $0.0 \%$ \\
\hline 8 & endurance/able to cope with stress & 6 & $10.7 \%$ & 10 & $13.5 \%$ \\
\hline 9 & responsibility & 13 & $23.2 \%$ & 17 & $23.0 \%$ \\
\hline
\end{tabular}


Tab. 2 - Requirement group testing (overview of results). Source: Author's own research

\begin{tabular}{|l|l|l|l|l|}
\hline \multicolumn{2}{|l|}{ Groups of tested requirements } & chi-square value & df & test result \\
\hline P & performance prerequisites and abilities & 20.3917250 & 9 & $\mathrm{H}_{0}$ rejected \\
\hline I & interpersonal abilities and skills & 3.9622747 & 4 & $\mathrm{H}_{0}$ not rejected \\
\hline O & $\begin{array}{l}\text { other psychological demands and require- } \\
\text { ments }\end{array}$ & 32.0041182 & 8 & $\mathrm{H}_{0}$ rejected \\
\hline
\end{tabular}

A statistically significant difference in the distribution of frequencies of requirements grouped together in the group marked $\mathrm{P}$, including performance prerequisites and abilities, was confirmed for $\&=0.001$ and $\&=0.01$, as proved by calculations in Tab. 3 .

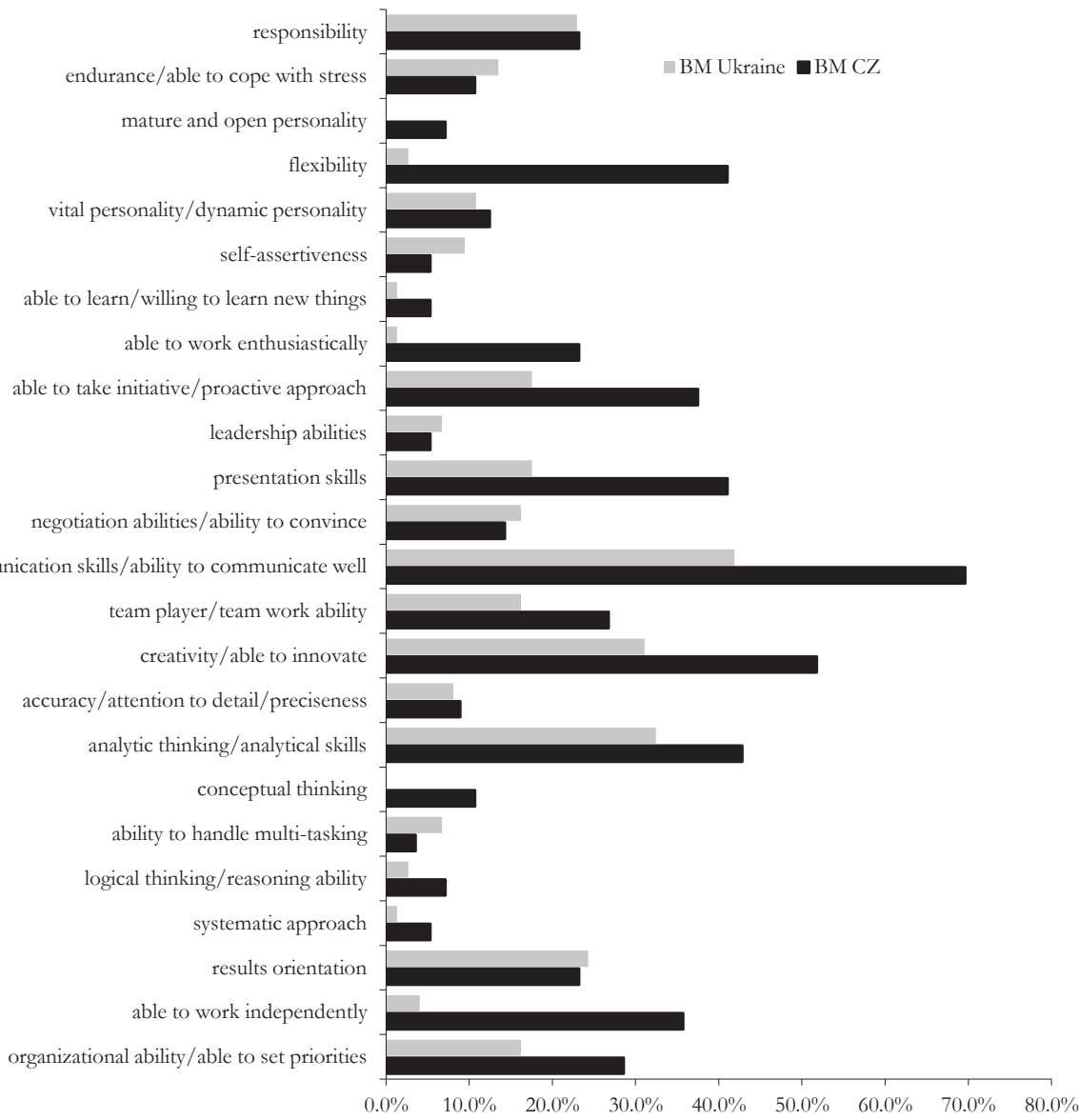

Fig. 1 - Comparison of the relative frequency of requirements for personality traits and skills of brand managers in the Czech Republic and Ukraine. Source: Author's own research. 


\subsection{Discussion}

In this sub-section, first the fulfilment of the set objectives and the results presented will be evaluated and discussed, followed by an assessment of benefits and drawbacks.

It is to be emphasized that the profession of a brand manager is not subject to uniform a priori standards. Therefore, particular job requirements are to be inferred from the job description and the given person specification (e.g. Armstrong, 2012). An analysis of relevant labour market data may thus compensate for an insufficient public reflection on the brand manager job.

Brand managers are involved in business activities in various ways. In a vertically structured organization, however, they rarely have direct subordinates, thus they must work with other departments in the role of a personal coordinator. Thus, it is no wonder that effective communication skills (the "ability to communicate well") represent the most frequent requirement in advertisements, a result which corresponds to business practices both in Ukraine and the Czech Republic. In business organizations, marketers act as intermediaries matching the organization's supply with market demand, listening to customers' needs and transferring information to executive departments. Having few executive powers of their own, brand managers are forced to take full advantage of their behavioural competencies. Despite having a coordinating role, their professional commitments and responsibilities make the job performance requirements of brand managers more variable than may be expected, as is reported in, e.g. Steenkamp (2017) and Keller (2013).

This section deals with the confirmation of the hypothesis (1). Almost a third of Ukrainian advertisers (32.4 percent) require that a candidate for the position of a brand manager possess analytical abilities as a basis for "decision-making" competencies, with such skills being necessary to process details and solve problems. The next most common psychological requirements presented are related to creativity, often expressed as the ability to innovate ( 31.3 percent), along with a "result orientation" behavioural competency. These results prove that employers are interested in how the person with a specific competency behaves, if she/he is performance-aware, taskfocused and purposeful enough to achieve reasonably demanding corporate goals. Steenkamp (2017), who has been studying global brands for more than 25 years, argues that members of brand management teams should embrace a range of skills and knowledge that distinguish them from common corporate marketers, a description which highlights their duties without listing particular skills. The last requirement expected by more than a fifth of employers surveyed is responsibility (23.0 percent), a factor which is based on conscientiousness - one of the Big Five personality dimensions. The fact that responsibility is among the most frequent requirements implies that Ukrainian advertisers are reaching out to more mature and independent individuals. The present research results illustrated in Tab. 1, however, do not provide enough data to further facilitate a discussion on the Big Five structural model.

The study outcomes confirm that creativity and analytical thinking - both necessary for success in product innovation as stated by Crawford \& Di Benedetto (2000) and Franková (2011) - rank among the top five psychological requirements for brand managers in Ukraine. Since innovation is the key factor of maintaining global competitive edge, a finding supported by professional sources, the more frequent occurrence of the "ability-to-innovate" requirement in job advertisements was an expected outcome. 
Concerning the hypothesis (2), Tab. 2 shows that changes in the representation of requirements were statistically insignificant at all levels for the group of interpersonal skills and abilities, even though the requirement for the ability to communicate effectively was featured in almost 70 percent of advertisements in the Czech Republic and more than 40 percent in Ukraine. Fig. 1 indicates further differences between employer preferences in Ukraine and the Czech Republic. The compared files differ considerably in the frequency of the requirements for flexibility, in the proactive approach and in the ability to work enthusiastically. In this context, it is appropriate to refer to Armstrong (2012), who points out that it is important not to place too much emphasis on personal traits (such as initiative and determination) in the advertisements, as prospective candidates may become distracted. Undoubtedly, it is beneficial for recruits to possess such qualities in performing brand manager tasks, thus it is important to identify these respective traits. When testing the group of performance prerequisites and abilities (marked P) - for details, see Tab. 3 - the Pearson test confirmed the difference at a five percent level of significance. As illustrated in Tab. 1, the requirements for abilities to work independently, setting priorities and approach problems systematically and for creativity components (e.g. logical and conceptual thinking) are imposed more often by Czech than by Ukrainian employers.

Despite no statistically significant change in the group of requirements for interpersonal skills and abilities, regarding the second research assumption a few differences were detected.

Certain constraints determine the scope and boundaries of the present paper. Firstly, the selection of the three Ukrainian regions Kiev, Lviv, and Dnipropetrovsk were made on the assumption that they may seem attractive to highly skilled knowledge workers. Secondly, the sample of recruitment ads neither encompass the whole industrial spectrum nor represent all types of advertisers. In other words, there is still room for further study.

The above limitations do not restrict the generalizability of the findings, with the present analysis extending the understanding of the human factor within brand-oriented marketing management. Moreover, the comparative approach allows for cross-national comparison, revealing differences and similarities between the two labour markets, thus initiating a more comprehensive discussion of the issue. To further broaden the scope of international comparative research into marketing position requirements, Slovak job advertisements are currently being analysed by the author of the present paper.

\section{CONCLUSIONS}

This research paper deals with the personality traits and competencies listed in advertisements for brand managers in Ukraine and the Czech Republic, highlighting the crucial role of these employees in brand-conscious companies across industries in a globally competitive environment. The analysis focuses on mapping personal qualities and skills that should be possessed or acquired by creative knowledge workers, and which are required by potential employers, who include them explicitly in recruitment advertisements. Due to the lack of input data typical of the chosen issue, an empirical research method was employed. An interdisciplinary approach was applied, as the theoretical background research encompassed several fields of study. The frequency of the advertised job requirements was examined using Berelson's content analysis technique. 
The primary objective was to verify the hypothesis (1) that brand managers are considered knowledge workers whose personality traits and soft skills arise from traits indicative of creative individuals. The research results have shown that creativity and analytical thinking, both necessary for successful product innovation, are among top five psychological requirements for brand managers in Ukraine. Due to the role of innovation in the international competition, a more frequent occurrence of creativity requirements in the Ukrainian set of advertisements was expected.

Another aim of the analysis was to compare the groups of personality requirements and soft skills posted on career sites in Ukraine and the Czech Republic as well as to test hypothesis (2) that employers in the two countries do not enumerate different job requirements for brand manager candidates. A textual comparison showed some differences in all sets of psychological requirements between Ukraine and the Czech Republic. The assumption of matching requirements in the group of performance prerequisites and abilities was rejected at a five percent significance level by an independence test using the criterion of chi-square distribution. The ability to communicate effectively was proven to be the most common shared requirement by both Czech and Ukrainian employers for brand manager candidates.

Hopefully, independent empirical research will further build on the current knowledge base, further updating the already complex delineations of brand manager requirements in job advertisements.

\section{Acknowledgements}

This paper was completed with the support of the College of Regional Development and Banking Institute (College Ambis).

\section{References}

1. Aaker, D. (1991). Managing Brand Equity: Capitalizing on the Value of a Brand Name. N. J.: The Free Press.

2. Aaker, D. (1996). Building strong brands. N. J.: The Free Press.

3. Abdolmohammadi, M. J. (2005). Intellectual capital disclosure and market capitalization. Journal of Intellectual Capital, 6 (3), 397-416. https://doi.org/10.1108/14691930510611139

4. Achrol, R. S., \& Kotler, P. (2012). Frontiers of the marketing paradigm in the third millennium. Journal of the Academy of Marketing Science, 40 (1), 35-52. http://dx.doi. org/10.1007/s11747-011-0255-4

5. Amabile, T. M. (2008). How to Kill Creativity. In Henry, J. (ed.) Creative Management and Development. (pp. 18-24). Los Angeles: SAGE Publications.

6. Armstrong, M. (2006). A Handbook of Human Resource Management Practice. London: Kogan Page.

7. Armstrong M. (2012). Armstrong's Handbook of Human Resource Management Practice. London: Kogan Page.

8. Aumayr, K. J. (2006). Erfolgreiches Produktmanagement: Tool-Box für das professionelle Produktmanagement und Produktmarketing. Wiesbaden: Gabler Verlag. 
9. Berelson, B. (1952). Content Analysis in Communication Research. Glencoe III, UK: The Free Press.

10. Bettinger, P., \& Merry, K. (2018). Follow-up study of the importance of mapping technology knowledge and skills for entry-level forestry job positions, as deduced from recent job advertisements. Mathematical and Computational Forestry \& Natural-Resource Science, $10(1), 15-23$.

11. Bontis, N. et al. (1999). The knowledge toolbox: a review of the tools available to measure and manage intangible resources. European Management Journal, 17 (4), 391-403. Retrieved April 2, 2018 from: https://pdfs.semanticscholar.org/b357/ 4ba9f951c04c38ad4bda201faee5a4f9b6a0.pdf

12. Chernatony, L. de (2009). Značka: Od vize k vyššm ziskìm [in Czech]. Brno: Computer Press.

13. Crawford, M. C., \& Di Benedetto, A. C. (2000). New Products Management. New York: McGraw-Hill.

14. Davenport, T. D. (2005). Thinking for living: How to Get Better Performance and Results from Knowledge Workers. Boston: Harvard Business Review Press.

15. Detmering, R., \& Sproles, C. (2012). Forget the desk job: Current role and responsibilities in entry-level job advertisements. College \& Research Libraries, 73 (6), 543-555. http://dx.doi. org $/ 10.5860 /$ crl-304

16. Drucker, P. F. (1993). Postkapitalistická společnost [in Czech]. Praha: Management Press.

17. Drucker, P. (1999). Challenges for the 21th Century. Oxford: Butterworth-Heinemann.

18. Dunbar, K., Laing, G., \& Wynder, M. (2016). A Content Analysis of Accounting Job Advertisements: Skill Requirements for Graduates. e-Journal of Business Education \& Scholarship of Teaching, 10 (1), 58-72. Retrieved April 14, 2018 from: https://files.eric.ed.gov/ fulltext/EJ1167332.pdf

19. Franková, E. (2011). Kreativita a inovace v organizaci [in Czech]. Praha: Grada Publishing.

20. Gorchels, L. (2005). The Product Managers Handbook. New York: McGraw-Hill.

21. Hall, C. S., Lindzey, G; Loehlin, J. C., \& Manosevitz, M. (1997). Úvod do teórií osobnosti [in Czech]. Bratislava: SPN.

22. Hlavsa. J. (1985). Psychologické qáklady teorie tvorby [in Czech]. Praha: Adademia.

23. Hroník, F. (2007). Jak se nespálit podrubé: strategie a praxe výbérovébo ř́zęeni [in Czech]. Brno: Motiv Press.

24. Kaba, A. (2017). Online library job advertisement in United Arab Emirates: a content analysis of online sources. Library Management, 38 (2-3), 131-141. http://doi.org/10.1108/ LM-07-2016-0058

25. Kapferer, J. N. (1998). Strategic Brand Management: Creating and Sustaining Brand Equity Long Term. London: Kogan Page.

26. Keller, L. K. (1993). Conceptualizing, measuring, managing customer-based brand equity. Journal of Marketing, 57 (1), 1-22. http://doi.org/10.2307/1252054 
27. Keller, L. K. (2008). Strategic brand management: building, measuring, and managing brand equity. New Jersey: Pearson Education.

28. Keller, L. K. (2013). Strategic brand management: building, measuring, and managing brand equity. Harlow: Pearson.

29. Kotler, P., \& Keller, L. K. (2012). Marketing management. New Jersey: Prentice Hall.

30. Kotler, P., \& Keller, L. K. (2013). Marketing management [in Czech]. Praha: Grada Publishing.

31. Kotler, P., \& Pfoertsch, W. (2006). B2B Brand Management. Berlin: Springer.

32. Kovacs, G., Tatham, P., \& Larson, P. D. (2012). What skills are needed to be a humanitarian logistician? Journal of Business and Logistics, 33 (3), 245-258. https//doi.org/10.1111/j.21581592.2012.01054.x

33. MINFIN. (2017). Ukraine's GDP in the first quarter was 2.1-2.3\% - MERT. Ministry of Economics and Development Affairs of Ukraine. Retrieved March 11, 2018 from: http:// minfin.com.ua/2017/04/28/27515875/

34. Mládková, L. (2004). Management znalostí v praxi [in Czech]. Praha: Professional Publishing.

35. Mládková, L. (2008). Management znalostních pracovníkỉ [in Czech]. Praha: C. H. Beck.

36. Nakonečný, M. (1998). Základy psychologie [in Czech]. Praha: Academia.

37. Nguyen, T. D., Dadzie, C., Davari, A., \& Guzman, F. (2015). Intellectual capital through the eyes of the consumer. Journal of Product \& Brand Management, 24 (6), 554-566. http:// dx.doi.org/ 10.1108/JPBM-03-2015-0837

38. Noe, R. A., Hollenbeck, J. R., Gerhart, B., \& Wright, P. M. (2017). Human Resource Management: Gaining a Competitive Advantage. New York: McGraw-Hill Education.

39. Pitra, Z., Mohelská, H. et al. (2015). Management transferu znalostí: od pruního nápadu ke komerčně úspěšné inovaci [in Czech]. Praha: Professional Publishing.

40. Řezanková, H. (2007). Analýza dat z dotazníkových šetrení [in Czech]. Praha: Professional Publishing.

41. Schwandt, T. A. (2001). The Dictionary of Qualitative Inquiry. London: SAGE Publications.

42. Schultz, T. W. (1981). Investing in People: The economics of population quality. Berkley (CA): University of California Press.

43. Sokil, O., \& Ubrežiova, I. (2017). The opportunity and threats for the selected Ukraine company in the entering the international markets. In Košičiarová, I., \& Kádeková, Z. (Ed.) Proceedings of the International Conference ICoM_2017: Managerial Trends in the Development of Enterprises in the Globalization Era (pp. 210-217). Nitra: Slovak University of Agriculture in Nitra, Faculty of Economics and Management. WOS: 000426613300062.

44. Subramaniam, M., \& Youndt, M. A. (2005). The Influence of Intellectual Capital on the Types of Innovative Capabilities. Academy of Management Journal, 48 (3), 450-463. http:// dx.doi. org/10.5465/AMJ.2005.17407911

45. Steenkamp, J. B. (2017). Global Brand Strategy: World-wise Marketing in the Age of Branding. London: Palgrave McMillan. 
46. Štikar, J., Rymeš, M., Riegel, K., \& Hoskovec, J. (2003). Psychologie ve světě práce [in Czech]. Praha: Univerzita Karlova, Karolinum.

47. Tomek, G., \& Vávrová, V. (2009). Jak zuýšit konkurenční schopnost firmy [in Czech]. Praha: C. H. Beck.

48. Triumph, T. F., \& Beile, P. M. (2015). The trending academic job market: An analysis of library position announcements from 2011 with comparisons in 1996 and 1988. College \& Research Libraries, 76 (6), 713-739. http://dx.doi.org/10.5860/crl.76.6.716

49. Truneček, J. (2003). Znalostnípodnik ve žnalostní společnosti [in Czech]. Praha: Professional Publishing.

50. Upshaw, L. B. (1995). Building Brand Identity: A Strategy for Success in a Hostile Marketplace. New York: John Wiley \& Sons.

51. Wroblowská, Z. (2016a). Brand manager as a Knowledge Worker. In Formánková, S. (Ed.) Proceedings of the International Conference on Management: Trends of Management in the Contemporary Society pp. 251-254. Brno: Mendel University in Brno. WOS: 000400581300054.

52. Wroblowská, Z. (2016b). Identification and Comparison of Requirements Placed on Brand Managers. Trends Economics and Management, 10 (26), 57-65. http://dx.doi.org/10.13164/ trends.2016.26.57

53. Wroblowská, Z. (2017a). Identification and Comparison of Requirements Imposed on Brand Managers: Cross-National Study in the U.S.A. and in the Czech Republic. Trends Economics and Management, 11 (29), 69-82. http://dx.doi.org/10.13164/trends.2017.29.69

54. Wroblowská, Z. (2017b). Comparison of Requirements for Brand Managers Responsible for the Competitiveness of Brands: Cross-National Study in the US and the Czech Republic. Journal of Competitiveness, 9 (4), 148-163. http://dx.doi.org/10.7441/joc.2017.04.10

55. Wroblowská, Z. (2018). Requirements for Brand Managers in Ukraine and the Czech Republic: Identification and Comparison. Trends Economics and Management, 12 (31), 115-125. http://dx.doi.org/10.13164/trends.2018.31.115

\section{Contact information}

RNDr. Zuzana Wroblowska, Ph.D.

College of Regional Development and Banking Institute

Department of Economics and Management

Crech Republic

E-mail: zuzana.wroblowska@ambis.cz. 


\section{Appendix:}

Two-dimensional analysis of a group of performance prerequisites and abilities. Source: Author's own research

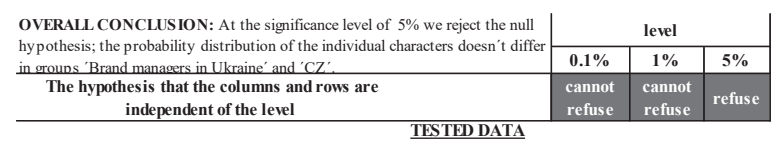

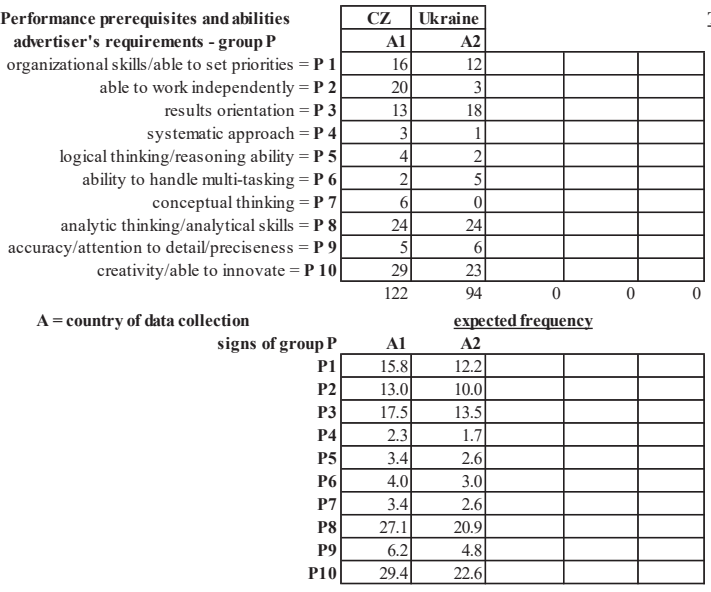
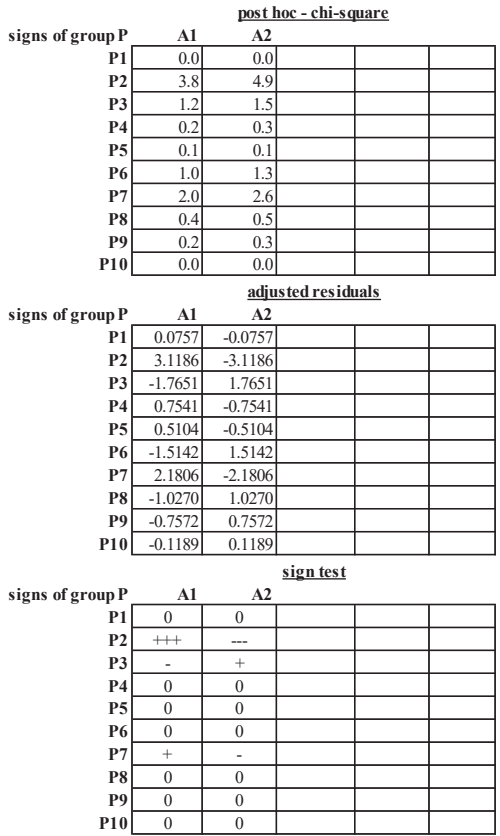
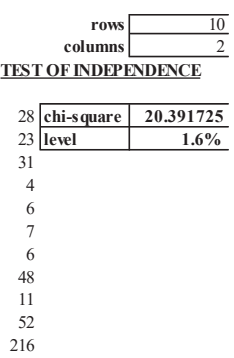

TEST OF INDEPENDENCE 